\title{
China Clean Energy Development direction
}

\author{
Shi HongXia \\ School of Earth Sciences and Resources \\ China University of Geosciences( Beijing) \\ Beijing, China \\ e-mail:hongxiashi@126.com
}

\author{
Liu Fuli \\ Architectural Design \& Research Institute \\ TsingHua University Company Limited \\ Beijing, China \\ e-mail:fuli_liu@126.com @,126.com
}

\author{
Wei Shen \\ School of Earth Sciences and Resources \\ China University of Geosciences( Beijing) \\ Beijing, China \\ e-mail: shenwei@,cugb.edu.cn
}

\begin{abstract}
At present the development of clean energy and sustainable development have become the main stream source of the world nowadays due to facing the serious global crisis of resources and environment. Investigation of energy situation and occurred problems of China and some typical countries, such as America and India are included in order to optimize the energy use and reduce the emission of China. This article presents the world's energy development direction of rapid adjustment combining with China's energy situation and puts forward that China's clean energy development direction is to arise energy saving consciousness, strengthens the development and utilization of new and renewable energy, draws lessons from foreign advanced technologies and experiences, accelerates energy structure adjustment, revise and highly energy policies, legal and economic means, promotes the implementation of the strategy of energy development. It will give great impetus to the development of economy and enhance economical and social benefits.
\end{abstract}

Keywords- clean energy; energy development strategy; energy situation development direction; energy demand; energy strategic reserve component

\section{INTRODUCTION}

Energy is closely related to the prospect of global climate, economic growth and sustainable development ${ }^{[1-}$ 4]. At present, the main energies include crude oil, natural gas and coal. According to the international energy agency, three kinds of energy resources on the earth can only be used for 40,50 and 240 years ${ }^{[5]}$.

In China the rapid economic development, more energy demands, consumption surge of oil, gas and coal the environment problem has become serious. At present, firstly $\mathrm{SO}_{2}$ gas emissions, secondly carbon emissions, methane and nitrous oxide emissions of greenhouse gases have become serious problems in the world and acidic rain amounted to $30 \%$ of the land area are ahead in the world.

About in 2025 China will be become largest country due to high emissions of carbon dioxide and surpass the United States according to prediction. Since the 1997 Kyoto environmental conference, all the countries have vigorously promoted the use of clean energy to improve the regional and global environmental quality as the goal, such as Denmark developing wind power, the United
States government implementing supporting policies for the domestic natural gas production, Norway with hydroelectric power efficient energy system, Germany for underground coal gasification and coal liquefaction. Based on the energy consumption structure, China can only promote to use clean energy and less polluted clean coal mining technology and the transformation of coal cleaning and recycling technology, to develope and utilize the novel energy, renewable energy and other clean energy, increase the environmental friendly energy ratio, reduce environmental pressure.

\section{DISCUSSED PROBLEMS}

\section{A. The world energy development strategy}

As worldwide demand for energy, almost all countries in the world are struggling to ease the energy problem according to their respective national conditions, considering the country's economic development and energy conservation, energy efficiency, the future energy demand forecasting, environmental conditions, restriction factors, to adopt corresponding countermeasures such as adjusting the energy consumption structure, actively develop new energy, build new offshore oil base, and research on energy saving and energy saving measures etc.

i) World's energy development strategy in the developed countries

With the change of the international energy market, the world developed countries have formulated the corresponding strategy, so as to ensure the stability of domestic energy supply. Mainly includes: 1) energy actively explore overseas markets including worldwide continuously the oil and gas exploration and development, intensify the competition for the world oil and gas resources and control.

ii) establishing and strengthening energy strategic reserve, the reason is that the strategic petroleum reserve is the most important way to oil consumers cope with the oil crisis. Therefore, the western countries are to establish a strategic oil reserve as the primary strategy of oil supply security.

iii) positive development and utilization of new energy and renewable energy, now Japan is doing work in developing the new energy, the solar energy, wind energy, fuel cells, hydrogen power, superconducting . At the same 
time, also actively develop the tides, waves, such as geothermal, garbage power generation of research and experimentation. American of the national comprehensive energy strategy determining the new energy development and utilization of goal is to develop advanced renewable energy technology, the development of unconventional methane resources, the development of hydrogen storage, distribution, and conversion technologies ${ }^{[6]}$.

iv) to improve energy utilization efficiency, strict energy-saving policy, countries all over the world especially in developed countries, has put the energy efficiency, energy saving as an important objective of energy development strategy .

5) to develop clean energy, since the Kyoto protocol was signed, all countries in the world in order to ensure the residents' health, improve the regional and global environmental quality as the goal, vigorously promote the use of clean energy. Developing wind power such as Denmark, the United States government implements are the supporting policies for the domestic natural gas production, Norway hydroelectric power efficient energy system, Germany for underground coal gasification and coal liquefaction etc.

\section{B. Energy development strategy in developing countries}

With global energy competition, developing countries on the issue of energy, also adopted a series of countermeasures, to ease the energy problem. Mainly include 1) to develop energy conservation activities, with legal and economic means to promote energy saving and efficiency increase 2) positive development and utilization of new energy and renewable energy as soon as possible to complete the process of renewable energy to replace conventional energy 3 ) increase more input to the energy industry, strengthen the energy utilization research 4) to absorb advanced technology experience, strengthening international communication and cooperation 5) to invest highly in education, strengthen the propaganda and education environment and energy, promote energy saving and new energy development.

In total, the new technological achievements in the rapid popularization and application of the energy industry and the entire energy industry transition from low to high technology, energy saving new products and new technology constantly emerging, all kinds of new energy and renewable energy development and utilization have made great progress. Energy product is to clean, the diversified development.

\section{CURRENT SITUATION OF ENERGY}

In recent years, our country has made great progress in the field of energy development, energy production has doubled in coal production, oil and gas exploration and development, large hydro-power stations, nuclear power development and the development of renewable energy, there are great achievements. On the other hand, our country has also become a large energy consumer, China economic and social development dependence on energy is higher than the developed countries ${ }^{[7]}$. At the same time, in the aspect of development and utilization of energy in our country, there are many problems.

\section{A. Production of energy can't meet the demand of energy consumption growth}

About 2050, China's energy output can reach till 3.54 billion tons of standard coal, the raw coal 3.35 billion tons, accounting for $67.7 \%$, Crude oil 230 million tons, accounting for $9.3 \%$, Natural gas 150 billion cubic meters accounting for $5.6 \%, 1.154$ trillion kilowatt hours of water and electricity, accounting for $4.5 \%$. However, in the new century our country economy presents a new rapid growth situation and energy production cannot meet the energy demand. at the beginning of the $21^{\text {th }}$ century, It can be predicted that China domestic energy supply gap will be high than 100 million tons of standard coal, 2030 is about 250 million tons of standard coal, about 460 million tons of standard coal by 2050 , about 0.1 of the energy demand in the years.

\section{B. Energy consumption structure is not reasonable}

Among our country energy consumption structure, coal accounted for more than $67 \%$, new energy, including natural gas, renewable energy, nuclear power and the ratio is very low. Now, our country oil production cannot meet the development of transportation, to increase of car ownership are to put forward new demand to energy. Our country has become a pure oil import country, there is a gradually increase in imports. As international high oil prices that carries a lot of pressure to the economic development of our country and also poses a threat to national economic security. In addition, long-term consumption of fossil fuels, high pollution and greenhouse gas emissions have put high pressure on China environment.

\section{Energy efficiency is not high}

Overall, China's current energy efficiency is lower than the international advanced level and is more than $10 \%$. Some of the main department of the national economy, such as industrial department, the transportation department, construction department and residents generally effect on the efficiency of low energy utilization

In fact we really need to use new efficient energysaving technology fully. Recent case studies of publicprivate RD\&D partnerships are documented in DOE/EE (2000), Geller and Thorne (1999), and Geller and McGaraghan (1996). For example, DOE/EE (2000) describes 11 public-private RD\&D partnerships that are estimated to have saved 5050 trillion Btu of energy to date, or about $\$ 30$ billion (1998\$) in energy costs. These savings are approximately enough to meet the energy needs of all of the citizens, 2 Annualized consumer cost savings are the energy bill savings in 1996 minus the annualized cost premiums for better equipment.

It is important to note that DOE does not take full credit for the entire stream of benefits produced by these technologies. Most of these accomplishments have involved partnerships with many stakeholders contributing in important ways. However, the success stories are numerous and diverse, and they suggest that the potential for future accomplishments is great.

Table 1 Cumulative net savings and carbon reductions from energh-efficient technologies developed with DOE fundings ${ }^{[8]}$. 


\begin{tabular}{cccc}
\hline $\begin{array}{c}\text { Energh-efficient } \\
\text { technology }\end{array}$ & $\begin{array}{c}\text { Net } \\
\text { present } \\
\text { value of } \\
\text { savings }\end{array}$ & $\begin{array}{c}\text { Annualized } \\
\text { consumer } \\
\text { cost savings } \\
\text { in 1996 }\end{array}$ & $\begin{array}{c}\text { Annual } \\
\text { carbon } \\
\text { reductions } \\
\text { in 1996 }\end{array}$ \\
\hline $\begin{array}{c}\text { Building } \\
\text { designsoftware } \\
\text { Refrigerator } \\
\text { compressor }\end{array}$ & 11.0 & 0.5 & 8 \\
$\begin{array}{c}\text { Electronic } \\
\text { ballast }\end{array}$ & 3.7 & 0.7 & 3 \\
$\begin{array}{c}\text { Flame retention } \\
\text { head oil burner }\end{array}$ & 5.0 & 0.5 & 3 \\
$\begin{array}{c}\text { Low-emissivity } \\
\text { windows }\end{array}$ & 3.0 & 0.3 & 1 \\
Totals & 28.7 & 3.4 & 16 \\
\hline
\end{tabular}

D. Development and utilization of new energy and renewable energy strategic understanding insufficiency

China has the largest population and low energy resources. At the same time, due to the unreasonable structure of energy utilization in China, it has become highly polluted to the environment. Therefore, development and utilization of new energy and renewable energy is the key source of the development in energy in our country. However, the current development of new energy and renewable energy in our country, the meaning of sustainable development and reduce environmental pollution has not been fully, broad understanding, to adjust the measurement to local conditions and to develop new energy and renewable energy policy implementation that is not enough.

\section{CHINESE CLEAN ENERGY DEVELOPMENT AND UTILIZATION OF THE CURRENT SITUATION}

Clean energy is the key source to emit no pollution including nuclear power, hydrogen power and renewable energy. Renewable energy refers to the raw material of renewable energy sources including hydro-energy, biomass energy, solar energy, wind energy, ocean energy, geo-thermal energy, biomass energy and it has the ability as an energy source and the use of biomass, organic waste including all kinds of agriculture and forestry, industry.

i ) Water, electricity, utilization of renewable resources, low cost, ecological cleaner, are the main sources of the world on the basis of water resources. First in the world, China is rich in hydro-power resources, the total around 378 million kilowatts, $16.7 \%$ of the world to the development and utilization of hydropower resources. According to statistics, small hydro-power those are China's fastest growing renewable energy sources. In 2004, small hydro-power installed capacity of 342 billion kilowatts, annual capacity of 110 billion KWH, accounts for about $40 \%$ of the total installed hydro-power and electricity. Since 1994, the construction of the world's largest conventional hydro-power station (18.2 million $\mathrm{MW}$ ) in the three gorges hydro-power station and the pumped-storage power station (2.4 million $\mathrm{kW})$ of Guangzhou, water and electricity technology among the world level, part has entered the world advanced level.

ii ) Wind energy: At present, our country have been constructed building wind farms mainly in Xinjiang, Inner Mongolia and coastal areas, imported equipment or technology introduction and parts assembly from China and the world wind energy technology.

iii) Solar energy: At present, is mainly divided into the solar thermal utilization of solar energy utilization and solar photo-voltaic power generation. At the early stage of solar energy, it is mainly used in daily life and the public in remote areas of electricity. China's "tenth five-year plan of solar energy utilization has put forward and implement to encourage" bright project ", rich in solar energy resources, electric power system power supply that is difficult for remote area construction and development of the solar oven and solar power generation facilities, effectively solve the Tibet, Xinjiang, Gansu and other regions of the living power.

iv) Hydrogen: China hydrogen use mainly (1) problem for the hydrogen in the field of science and cutting-edge technology to carry out the basic research (2) fuel cell, fuel cell engine and vehicle system with complete independent intellectual property rights of core technology (3) to launch the filling stations such as the hydrogen infra-structure and fuel cell buses run the project, to develop the hydrogen transportation commercially prepared (4) a breakthrough in study of hydrogen production bacteria (5) research on hydrogen production bacteria, organic wastewater of hydrogen, methanol reforming hydrogen production.

v ) Biomass energy utilization, biomass energy by photo-synthesis of plant and solar power and solar energy is stored in the plants on the earth. Through the biomass conversion technology, it can be efficiently used as biomass energy, production of clean fuel, alternative fuels such as coal, oil and natural gas, production of electricity. At present, in thermal chemical conversion technology, China has built the two big ethanol production base, formed the annual production of 1 million tons of production capacity; Sugar mill co-generation and rice husk power installed nearly 2 million kilowatts. In terms of bio-logical chemical conversion, China has become a stage of business mainly agricultural bio-gas and bio-gas projects that are the main sources of livestock and also the poultry farming is the biogas technology used for the development of country in the world.

vi) Ocean energy use: mainly for tidal power, tidal power station have been installed recently in China's total capacity of $5.65 \mathrm{MW}$.

vii) Geo-thermal energy use: mainly for the heating and geothermal power.

viii) Nuclear power: mainly for nuclear power, China's operation of Qinshan, Daya bay and Ling Ao 11 units, Tianwan nuclear power station, a total installed capacity is 9.11 million Kilowatts.

\section{CHINA CLEAN ENERGY DEVELOPMENT DIRECTION}

In recent years, our country has made great progress in the field of energy development, but there are many problems in the development and utilization of energy 
such as energy production that cannot meet the demand of energy consumption growth, unreasonable structure of energy, low energy efficiency, the development and utilization of new energy and renewable energy strategic understanding insufficiency $^{[9,10]}$. Therefore, China's energy development strategy should pay attention to insist for a long time to save energy and reducing consumption, energy efficiency, accelerate energy structure adjustment and vigorously to develop clean energy and a positive development and utilization of renewable energy. At the same time it will measure to promote the implementation of the strategy. This article will be the world's energy development direction of rapid adjustment combined with China's energy situation and put forward China's clean energy development direction lies in the following aspects:

i) Train their consciousness of energy conservation

At present, our country energy waste phenomenon is more serious, a lot of places of energy waste phenomenon has not been caused enough attention and concern. More saving energy and reducing consumption in the whole society and cultivate the consciousness of energy conservation, energy development plays a decisive role in our country.

ii) To strengthen the understanding of the development and utilization of new energy and renewable energy

Along with economic development and increased in the awareness of environmental protection, new energy development and utilization are the main attention of the countries all over the world. Current irrational energy structure in China, the understanding of the development of new energy and renewable energy is not enough, it should be strengthened the understanding of this area, to promote the development of China's energy.

iii) draw lessons from foreign advanced technology and experience, speed up the adjustment of energy structure

Recently, due to the unreasonable energy structure in our country, has great pressure on the environment. In order to protect the environment, it should be actively absorb and promotion of domestic and foreign advanced technology in the field of energy, promote the adjustment of energy structure, realize the sustainable development of energy.

iv) Revise and energy policy

In order to promote the development of energy, should play a role in the policy of the new century energy strategy, to implement the service function and the safeguard mechanism. To strengthen the research on energy policy in the new century and investment of funds, experience and achievements of foreign energy policy, combined with the reality of our country, to establish and perfect our energy policy.

$\mathrm{v}$ ) the legal and economic means, promote the implementation of the strategy of energy development

The legal and economic means can be used to promote the implementation of China's energy policy laws and regulations, so as to guarantee the implementation of the strategy of energy development. If the countries can adopt the method of energy tax, to control the growth of energy consumption, and guide the energy production and energy consumption, it will be developed to reduce carbon emissions.

\section{REFERENCES}

[1] UNEP (United Nations Environment Program), EPO (European Patent Office), ICTSD (International Center for Trade and Sustainable Development). Patents and Clean Energy: Bridging the Gap between Evidence and Policy[R]. 2010.

[2] Anoja Wickramasinghe. Energy access and transition to cleaner cooking fuels and technologies[J]. Energy Policy39(2011)75677574

[3] I'. Kotcio $־$ glu. Clean and sustainable energy policies in Turkey[J] Renewable and Sustainable Energy Reviews 15 (2011) 5111-5119

[4] Marcos Fava Neves. Clean energy policies for China: the case of ethanol. http://dx.doi.org/10.1108/17561371011097768

[5] [2]Zhang wei. Five clean eneygy of developing direction in China[J].Science news, 2004,(17).

[6] Yang lihua, Li jieli. Clean energy economy: America experience and China development [J].Market Economy.2012,(1).

[7] Yao fei, Zhao zhonghua, Yuzhufeng. Analysis of China clean energy situation [J]. Group economy research,2007,(1).

[8] Marilyn A. Brown. Energy Efficiency and Renewable Energy Program. Market failures and barriers as a basis for clean energy policies[J]. Energy Policy 29 (2001) 1197-1207

[9] Chen Xinghua. Journal of North China Institute of Technology(Social Science) [J], 2005,(05).

[10] Valentina Bosetti. Linking reduced deforestation and a global carbon market: implications for clean energy technology and policy flexibility[J]. Environment and Development Economics:127:

doi: $10.1017 / \mathrm{S} 1355770 \times 10000549$ 